\title{
Changes in the biochemical status of common carp juveniles (Cyprinus carpio L.) exposed to ammonium chloride and potassium phosphate
}

\author{
K. Kofonov ${ }^{1^{\star}}$, O. Potrokhov ${ }^{1}$, N. Hrynevych ${ }^{2}$, O. Zinkovskyi ${ }^{1}$, O. Khomiak ${ }^{2}$, \\ O. Dunaievska ${ }^{3}$, O. Rud ${ }^{4}$, L. Kutsocon ${ }^{4}$, V. Chemerys ${ }^{5}$, B. Gutyj ${ }^{5}$, L. Fijalovych ${ }^{3}$, \\ J. Vavrysevych ${ }^{5}$, V. Todoriuk ${ }^{5}$, K. Leskiv ${ }^{5}$, P. Husar ${ }^{6}$, P. Khumynets ${ }^{5}$ \\ ${ }^{1}$ Institute of hydrobiology NAS of Ukraine, Kyiv, Ukraine \\ ${ }^{2}$ Bila Tserkva National Agrarian University, BilaTserkva, Ukraine \\ ${ }^{3}$ Zhytomyr College of Pharmacy, Zhytomyr, Ukraine \\ ${ }^{4}$ Rivne State Humanitarian University, Rivne, Ukraine \\ ${ }^{5}$ Stepan Gzhytskyi National University of Veterinary Medicine and Biotechnologies, Lviv, Ukraine \\ ${ }^{6}$ Ferenc Rákóczi II. Transcarpathian Hungarian Institute, Beregszász, Transcarpathia, Ukraine
}

*Corresponding author E-mail: Kofonov.K@nas.gov.ua; bvh@ukr.net

Received: 13.08.2020. Accepted 18.09.2020

\begin{abstract}
Biogen elements that enter the water in large quantities are one of the main pollutants in the aquatic environment. They lead both to eutrophication of the reservoir and a decrease in the viability of young fish, acting as toxin. The energy enzyme activity (lactate dehydrogenase and succinate dehydrogenase), nitrogen (glutamate dehydrogenase) metabolism, dephosphorylation processes, and immune protection (by alkaline phosphatase activity) under the long-term action of ammonium nitrogen and phosphorus phosphates was studied. The biological object of research were 30-45 day common carp juveniles (Cyprinus carpio L.). According to our results, the peculiarities of the adaptive reactions of young carp to the action of these compounds have been established. We revealed, that under the loading of ammonium nitrogen, the activity of the processes of anaerobic digestion of energy-intensive complex increases directly in the organs of neutralization and excretion of nitrogenous compounds, namely in the gills. In general, the body of the carp due to these actions reduces the total energy consumption for maximum survival in these environmental conditions. We registered, that under the influence of elevated concentrations of phosphorus phosphates, oxidation of biogen elements to the body's energy needs in the presence of oxygen was observed. The processes of immune defense and dephosphorylation, for which LPh is responsible, also the detoxification, the excretion of nitrogenous substances from the body of carp (GDG) occurred differently depending on the chemical nature of the toxin. Thus, under the influence of ammonium nitrogen there was an increase in the activity of LPh in the highest concentrations of the toxin, and the activity of GDG decreased to reduce the production of ammonia, to avoid endogenous intoxication. Through these load of potassium monophosphate, the rise in the activity of immune defense processes and the involvement of ammonia in the cycle of tricarboxylic acids due to reamination to the energy supply of the processes of counteracting the weak but chronic toxic effects of orthophosphate ion. Under the load of ammonium chloride was observed not only the use of "traditional" energy substrates - glycogen and lipids, as well as proteins, which indicates the high toxicity of this compound for the body of young carp. Through the action of orthophosphate ion, the active use of lipids and even the activation of gluconeogenesis at maximum concentrations, as a reaction to weak long-term chemical stress.
\end{abstract}

Keywords: juvenile common carp, ammonium nitrogen, orthophosphate ion, toxicity, enzymatic activity, energy substrates.

\section{Introduction}

Hydrobionts, which include young fish, are constantly under the load of various environmental factors, many of which, beyond the optimal values for each species, cause changes at all levels of biological organization - from cellular to the level of the organism as a whole. There is a significant amount of work on the influence of environmental factors on the body and the regulation of its functions in fish, including temperature, oxygen content in water (Martseniuk et al., 2017; Martseniuk et al., 2018; Prychepa et al., 2019; Potrokhov et al., 2019; Vodianitskyi et al., 2020) and anthropogenic pollution (Sychov et al., 2017; Grynevych et al., 2018; Prychepa et al., 2019; Boyko \& Brygadyrenko, 2019; Rudenko et al., 2019; Gutyj et al., 2012; Bojko et al., 2020; Piven et al., 2020). The negative impact of it on the environment is multifaceted and greatly reduces the quality of surface 
waters. One of the essential elements of water pollution is the receipt of excessive amounts of substances containing biogen elements - nitrogen and phosphorus. According to some data, in the surface waterbody of the Ukrainian section of the Dnieper River, the content and ratio of inorganic forms of nitrogen and phosphate ions undergo significant fluctuations. these compounds are the main component in the composition of industrial, urban effluents, leachates from agricultural lands, mineral fertilizers and wastewater of various livestock complexes and poultry farms. In addition to exogenous intake, there is endogenous contamination with nitrogen and phosphorus substances from the remains of dead organisms. Inorganic nitrogen and phosphate ion are the final products of decomposition and mineralization of organic matter (Randall \& Tsui, 2002; Prysiazhniuk et al., 2019).

In excess, these ions can significantly affect the $\mathrm{pH}$ value of water, and some nitrogen substances adversely affect the viability of aquatic organisms (Wurtsbaugh et al., 2019). The above facts indicate the multidirectional nature of the effects of nitrogen and phosphorus compounds. On the one hand, biogen elements are the basis of producers' nutrition and the base of bio productivity of any aquatic ecosystem. However, a significant amount of these substances in water worsens the physiological state of aquatic organisms and even limits the bio productivity of water bodies. On the other hand, some nitrogen and phosphorus compounds, even in small quantities, are broad-spectrum toxins that adversely affect the viability of aquatic organisms.

In the aqueous medium, ammonium nitrogen comes in two forms: molecular (non-ionized) ammonia (NH3) and ammonium ion ( $\mathrm{NH} 4+$ ). The latter is less permeable to the biological membranes of fish gills and, accordingly, penetrates the body with less intensity (Camargo \& Alonso, 2006; Lotter \& Anderson, 2012). When ammonia penetrates through the gills from water, it can damage fish cells and tissues (Smart, 1976; Randall \& Wright, 1987; Francis-Floyd et al., 2009; Huff et al., 2013).

The toxicity of inorganic forms of nitrogen, in particular ammonia, for aquatic organisms, including fish, has been studied in detail and widely covered in many scientific documents (Tilak et al., 2002; Boudreaux et al., 2007; McKenzie et al., 2009; ElShebly \& Gad, 2011; Naidu et al., 2017). High concentrations of ammonia cause symptoms of neuro-paralytic and general poisoning in fish. It has been established that ammonia concentrations higher than $0.2 \mathrm{mg} / \mathrm{dm}^{3}$ reduce the viability of fish (Colt \& Tchobanoglous, 1976). Despite the above data, the study of the effects of ammonium nitrogen on the body of fish, in particular their young, has been insufficiently studied.

Together with nitrogenous substances, a significant amount of phosphorus compounds enters the reservoirs, which in excessive amounts lead to negative consequences for water bodies (Ulén \& Weyhenmeyer, 2007; Whitehead et al., 2009). The inorganic content of phosphorus substances in the reservoir changes dynamically during their absorption by biota and from their exogenous inflow with effluents. The main available forms of aqueous phosphorus are orthophosphate and phosphorus esters. It is part of many components of organisms, but a significant amount of it can also have a detrimental effect on aquatic flora and especially fauna (Liu et al., 2003; Chukwu \& Okpe, 2006; van Bussel et al., 2013; Strauch et al., 2019).

Fish are known to be more sensitive to toxins in the early stages of ontogenesis than in adulthood or later. Young fish are also vulnerable to the harmful effects of phosphorus compounds (Kim et al., 2013). The effect of phosphates on fish and their young is extremely poorly understood.

Thus, our research aim was to study the enzyme activity (lactate dehydrogenase and succinate dehydrogenase) and nitrogen (glutamate dehydrogenase) metabolism, dephosphorylation processes and immune protection (by alkaline phosphatase activity) under the long-term action of ammonium nitrogen and phosphorus phosphates in 30-45 days common carp juviniles (Cyprinus carpio L.).

\section{Materials and methods}

Chronic toxicological studies were performed at the Bila Tserkva Experimental Hydrobiological Station of the Institute of Hydrobiology of the National Academy of Sciences of Ukraine. Experiments to determine the effect of different concentrations of ammonium nitrogen and phosphorus phosphate ions on the viability and physiological condition of young fish were performed for 14 days in aquariums with a capacity of $30 \mathrm{dm}^{3}$ so that the ratio of fish to active solutions of toxins exceeds 100 300 times. The oxygen content was maintained using Tetratec APS 300 aerators. The 40 specimens of this year's carp with a length of 22.0-32.6 mm and a weight of 0.41-1.31 g were placed in the experimental aquariums. The condition of the fish was monitored round-the-clock observations.

The control group of fish was in a similar volume aquarium with water from the river Ros, in which the concentration of ammonium nitrogen was $0.21 \mathrm{mg} \mathrm{N} / \mathrm{dm}^{3}$, phosphorus $-0.06 \mathrm{mg} \mathrm{R} / \mathrm{dm}^{3}$, which is much less than the MPC of the farm.

Ammonium chloride at a concentration of 1.0-15.0 mg N/dm ${ }^{3}$ and potassium monophosphate at a concentration of $0.5-5.0$ mg $\mathrm{P} / \mathrm{dm}^{3}$ were used. The specified concentrations of nitrogen in water were prepared by dissolving $\mathrm{NH}_{4} \mathrm{Cl}$, and phosphorus phosphate dissolving $\mathrm{KH}_{2} \mathrm{PO}_{4}$ in water from the river Ros. Daily replacement of $1 / 3$ of drug solutions in experimental containers were changed. The guidelines of bioethics were investigated during the experiments. The minimum number of fish was used for wide statistical reliability of the results. Methods of spectrophotometry and photocolorimetry were used to determine the biochemical parameters of fish. Enzyme activity was determined on a UNICO-2800UV spectrophotometer at wavelengths of 365, 530 and $420 \mathrm{~nm}$. The activity of lactade dehydrogenase (LDH) and alkaline phosphatase (LPh) was determined using kits for clinical diagnosis "LDH", "Alkaline phosphatase" (LLC SPE Philisit-Diagnostics, Ukraine). Succinate dehydrogenase (SDG) activity was determined according to the photometric method of Eshchenko and Volsky (Eshchenko \& Volskyi, 1982). The activity of glutamate dehydrogenase (GDG) was established by the method of Khokhlov et al. (1990).

The content of organic compounds was determined by the photometric method on a photoelectro colorimeter KFK-2MP at a wavelength of 750,530, and $620 \mathrm{~nm}$. The total protein content in the muscles and gills was determined according to the Lowry 
method, the change of total lipids - with the possibility of a set for local diagnosis "Total lipids" (LLC SPE Phyllisit-Diagnostics, Ukraine), and glycogen was used by the anthrone method (Lowry et al., 1951).

\section{Results and discussion}

Under the influence of ammonium chloride, we observed changes in the activity of energy metabolism enzymes (LDH and SDH) in young carp. In the muscles of fish significantly reduced the activity of LDH (Fig. 1) in concentrations of $2.5-15.0 \mathrm{mg} \mathrm{N} / \mathrm{dm}^{3}$ by 37.4-50.0\% compared to the control. In carp gills, on the contrary, the activity of the enzyme increased, apparently due to the transition to an anaerobic type of energy supply of detoxification and excretion of ammonia.

The activity of the SDH in these tissues at all quantities was significantly degraded (Fig. 2), demonstrating the body's response to the toxic effects of ammonium by inhibiting aerobic energy generation processes. At all concentrations, we observed a decrease in muscle enzymatic activity by $37.3 ; 47.7 ; 52.6$ and $59.7 \%$ compared to control. In the gills, the fall in enzyme activity was $18.5 ; 32.7 ; 44.8$ and $46.9 \%$ relative to control values. Such changes are in complete agreement with the literature, as inhibition of the SDH activity often correlates with the growth of the LDH (Chandravathy \& Reddy, 1996; Prychepa et al., 2019).

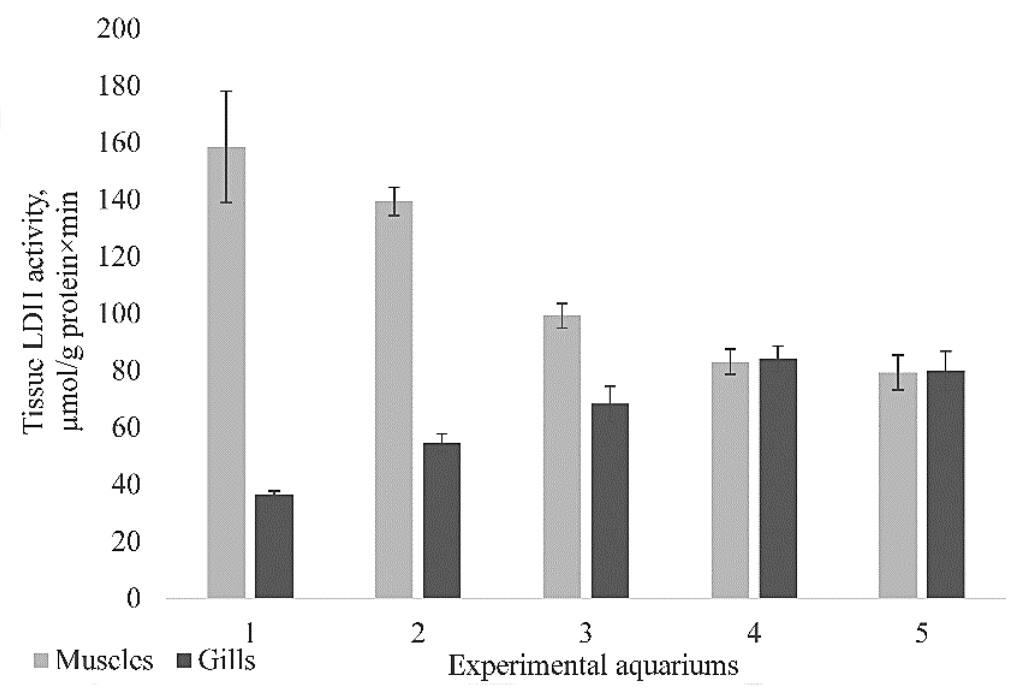

Fig. 1. The LDH activity in the tissues of young carp under the chronic action of high concentrations of ammonium chloride. $n$ $=40$. Here and then: 1 - control $\left(0.21 \mathrm{mg} \mathrm{N} / \mathrm{dm}^{3}\right) ; 2-1 \mathrm{mg} \mathrm{N} / \mathrm{dm}^{3} ; 3-2.5 \mathrm{mg} \mathrm{N} / \mathrm{dm}^{3} ; 4-5 \mathrm{mg} \mathrm{N} / \mathrm{dm}^{3} ; 5-15 \mathrm{mg} \mathrm{N} / \mathrm{dm}^{3}$

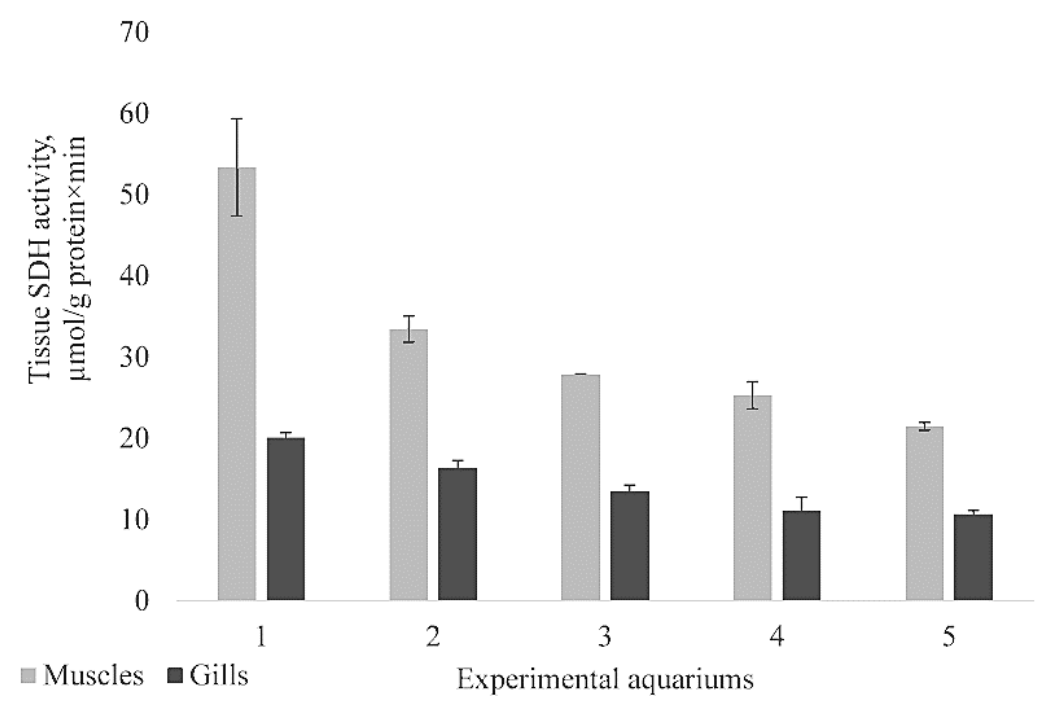

Fig. 2. The activity of SDH in the tissues of young carp under the chronic action of high concentrations of ammonium chloride.

The LPh activity in carp muscles at low quantity of ammonium 1.0 and $2.5 \mathrm{mg} \mathrm{N} / \mathrm{dm}^{3}$ significantly decreased by 69.7 and $58.0 \%$ relative to control, and at 5.0 and $15.0 \mathrm{mg} \mathrm{N} / \mathrm{dm}^{3}$ increased in 1.2 and $40 \%$ (Fig. 3). Accordingly, the fall in activity may be due to the lack of need to enhance dephosphorylation processes at this level of exposure. However, at higher concentration there is a maximization of the LPh activity, and at the highest amount there is a gradual depletion and inhibition of immune function with long-term exposure to ammonium nitrogen (Li et al., 2016). A similar pattern was observed in the gills, but the maximum growing in activity was 2.4 times at a amount of $2.5 \mathrm{mg} \mathrm{N} / \mathrm{dm}^{3}$, and subsequent concentrations of 5.0 and $15.0 \mathrm{mg} \mathrm{N} / \mathrm{dm}^{3}$ at $46.4 \%$ higher, and then $18 \%$ below control values.

The level of the GDH activity for exposure to ammonium chloride in carp tissues changed as follows. There was a correlated decrease in activity (Fig. 4), probably to reduce the amount of endogenous ammonia production, and consequently a fall in the value of aerobic energy generation pathways (reduction in SDH activity) and activation of anaerobic pathways (increase in LDH activity) to counteract ammonium stress. Changes in the direction of reduce relative to the control in tissues of mixed compositions $65.4 ; 73.0 ; 60.0$ and $83.3 \%$ relative to control and $12.4 ; 75.0 ; 83.3$ and $80.6 \%$ in the carp gills 


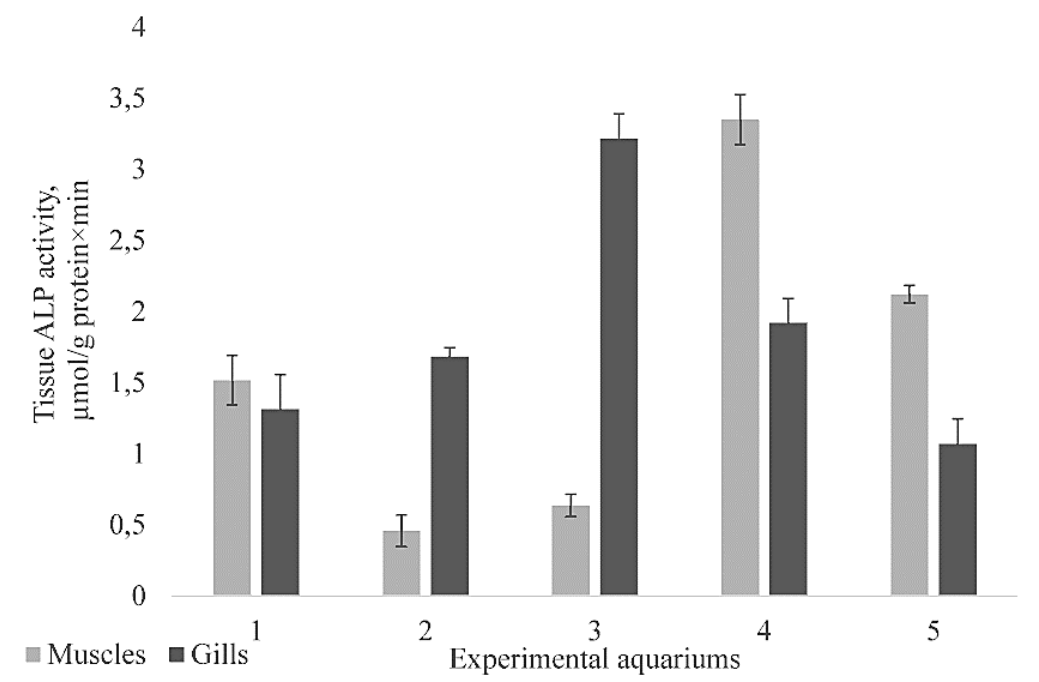

Fig. 3. The activity of LPh in the tissues of young common carp under the chronic action of high concentrations of ammonium chloride.

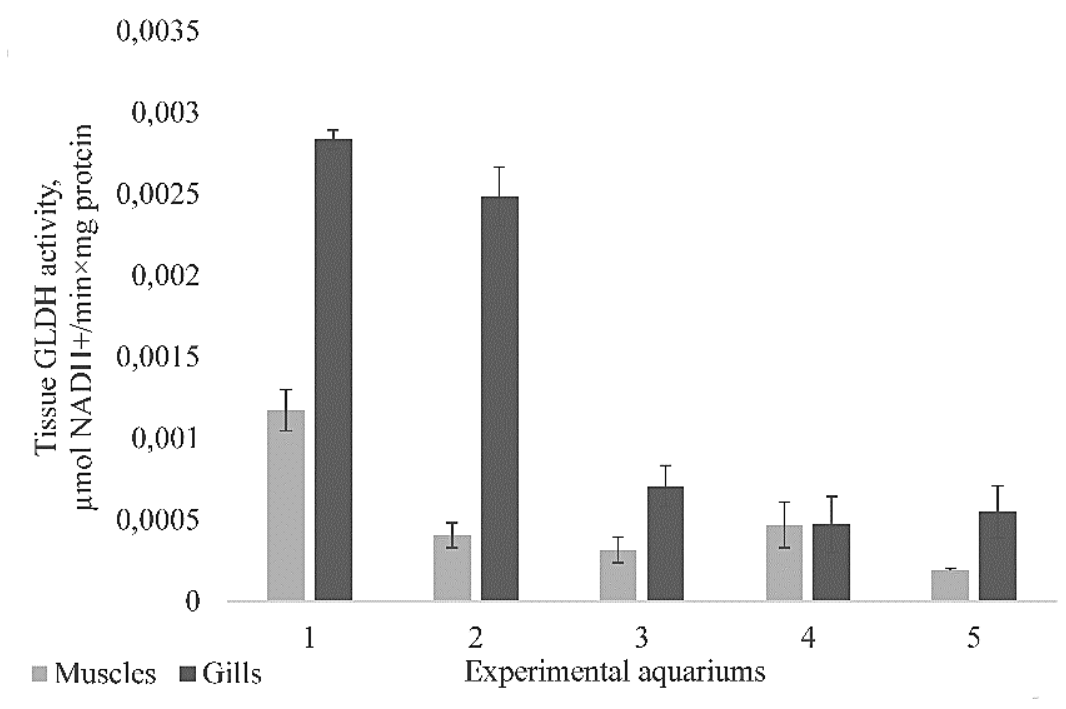

Fig. 4. The activity of GDH in the tissues of young common carp under the chronic action of high concentrations of ammonium chloride. $n=40$

In the carp tissues, we recorded the following changes in the protein (Fig. 5), the lipids (Fig. 6) and the glycogen (Fig. 7), which indicate the peculiarities of its adaptive response to the water pollution. At all concentrations of ammonium nitrogen, the protein content in muscle tissue gradually decline with increasing concentration of the ammonium chloride by $9.4 ; 20.0 ; 28.1$ and $45.7 \%$ compared to control. In the tissues of the gills recorded a significant fall in the protein content by $6.7 ; 11.0 ; 24.3$ and $36.0 \%$ relative to the amount of protein in the control group of fish.

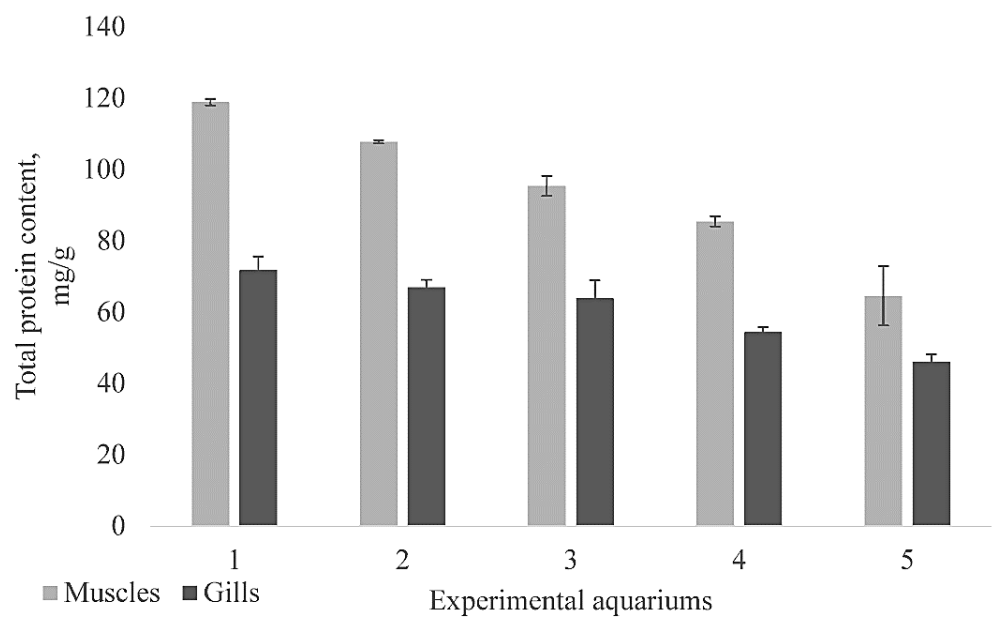

Fig. 5. The content of total protein in the tissues of young carp under the chronic action of high concentrations of ammonium chloride. 
60

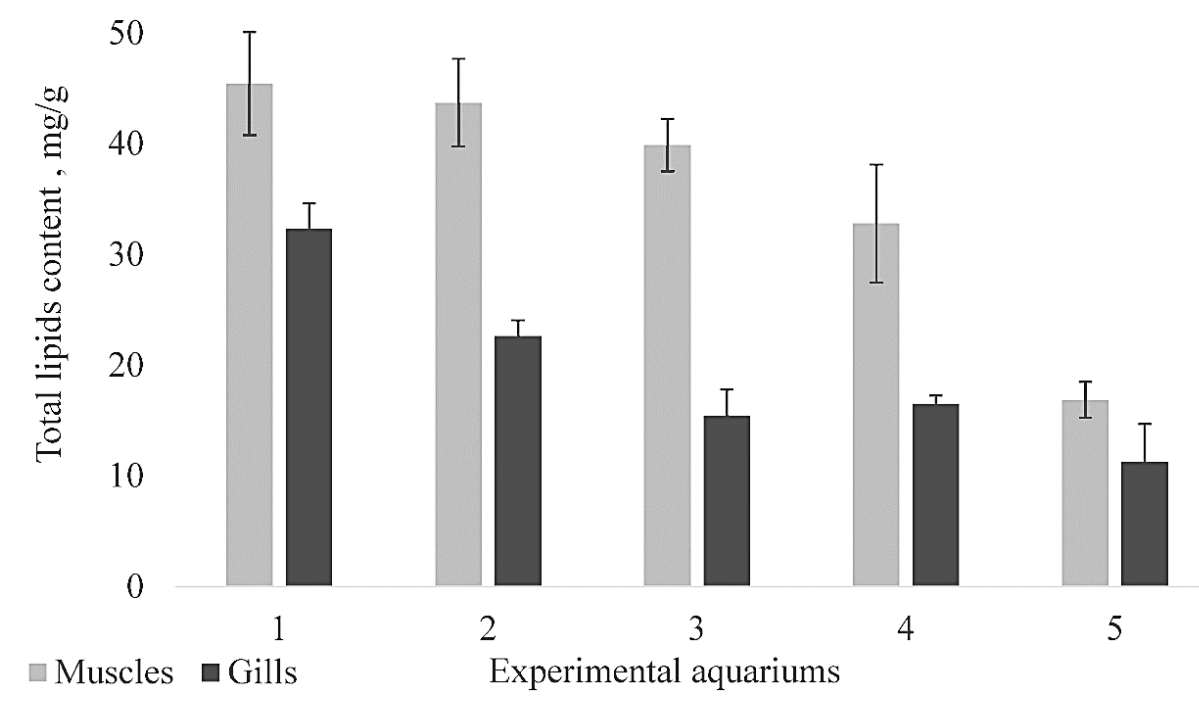

Fig. 6. The content of total lipids in the tissues of young common carp under the chronic action of high concentrations of ammonium chloride.

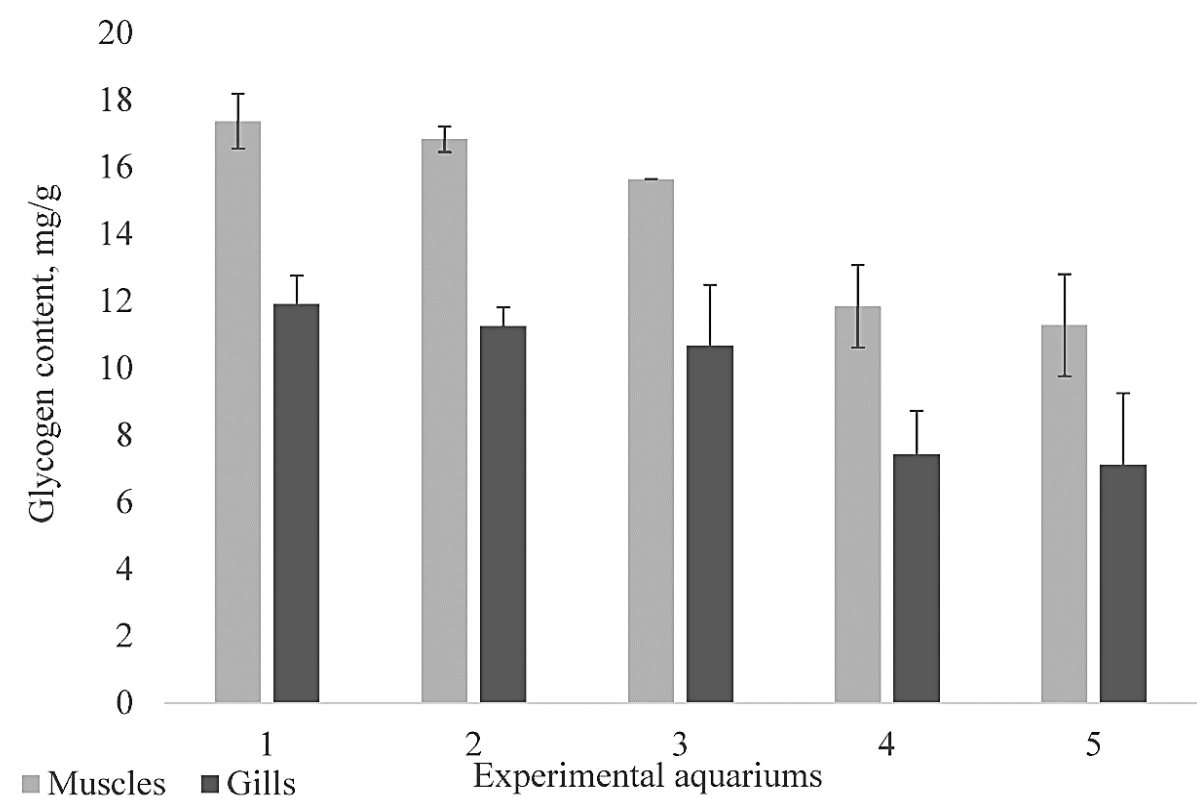

Fig. 7. The glycogen content in the tissues of young common carp under the chronic action of high concentrations of ammonium chloride.

The lipid content also decreased by 4.0; $12.2 ; 28.0$ and $63.0 \%$ in muscle relative to controls. Their active use for energy supply of ammonia detoxification processes is obvious. Similar reductions of 30-65\% relative to control were observed in gill tissues. Active use of glycogen for energy supply of metabolic processes of the body was observed at concentrations of ammonium ions 5 and $15 \mathrm{mg} \mathrm{N} / \mathrm{dm}^{3}$. At these condition, there was a 32-35\% fall in the glycogen content in the muscles and 38-40\% in the gills relative to control, indicating the toxicity of these amount to fish. Such changes point to an adequate response of carp to the effects of ammonium nitrogen and against the background of other index indicate changes in the body to increase the processes of cleavage of energy substrates to maintain energy homeostasis due to water pollution by toxin.

The activity of LDH in carp tissues under the action of potassium monophosphate was as follows. In both studied tissues there was a significant tendency to reduce the activity of anaerobic processes (Fig. 8). In the muscles, the difference with the control index was $53.2,17.7,45.2$ and $70.7 \%$. In the gill tissue, significant changes were recorded in the last two concentrations, which point to low toxicity and the absence of significant energy consumption to counteract this amount of toxin.

The activity of aerobic processes correlates with LDH data. In the muscles there was an increase in enzymatic activity by 29.0 and $69.3 \%$ at quantity of 0.5 and $1.0 \mathrm{mg} \mathrm{P} / \mathrm{dm}^{3}$, while at subsequent concentrations the growth was 2.0 and 2.12 times relative to control (Fig. XIX). The level of LDH activity in the gills showed a tendency to rise at low concentrations of potassium monophosphate by 30.7 and $60.3 \%$ and unreliable relative to control the positive difference in activity at high amount of toxin. 


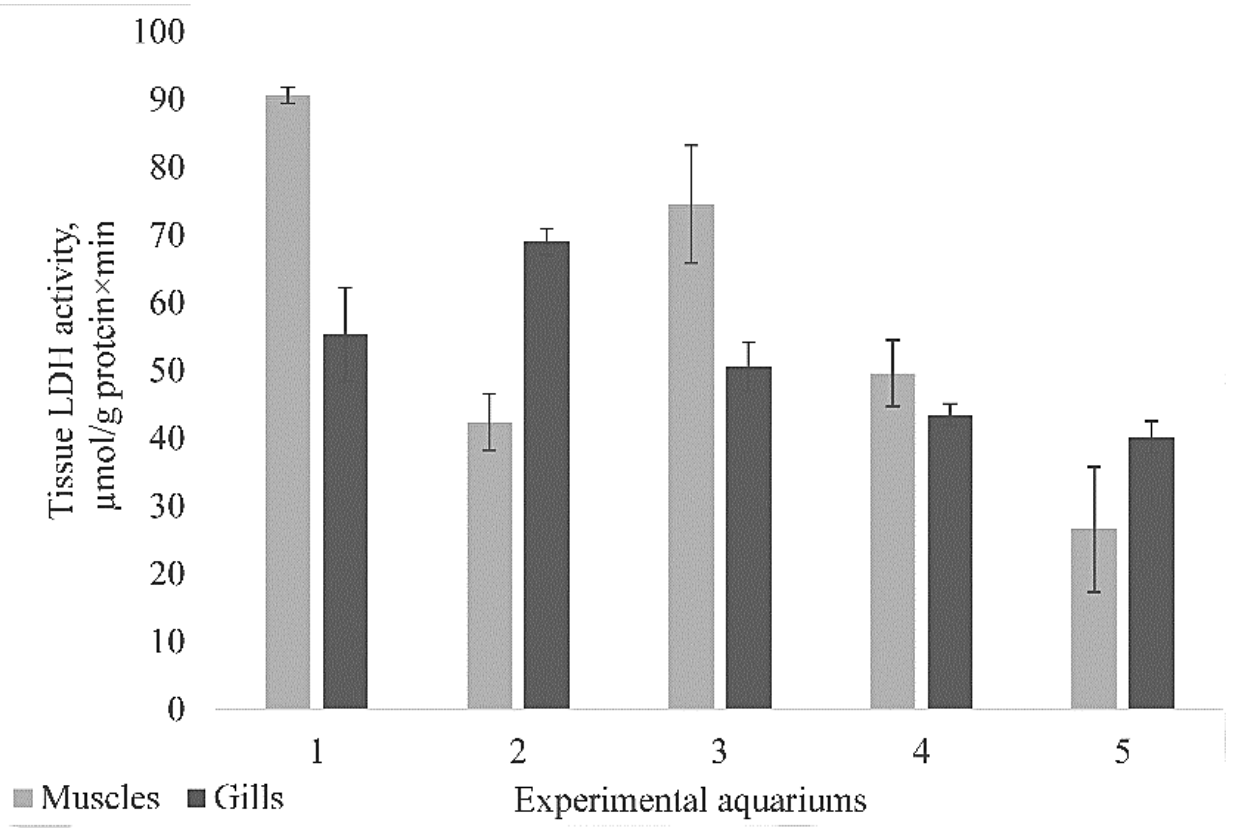

Fig. 8. The LDH activity in the tissues of young common carp under the chronic action of high concentrations of potassium

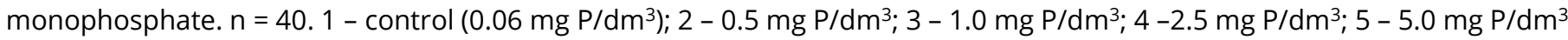

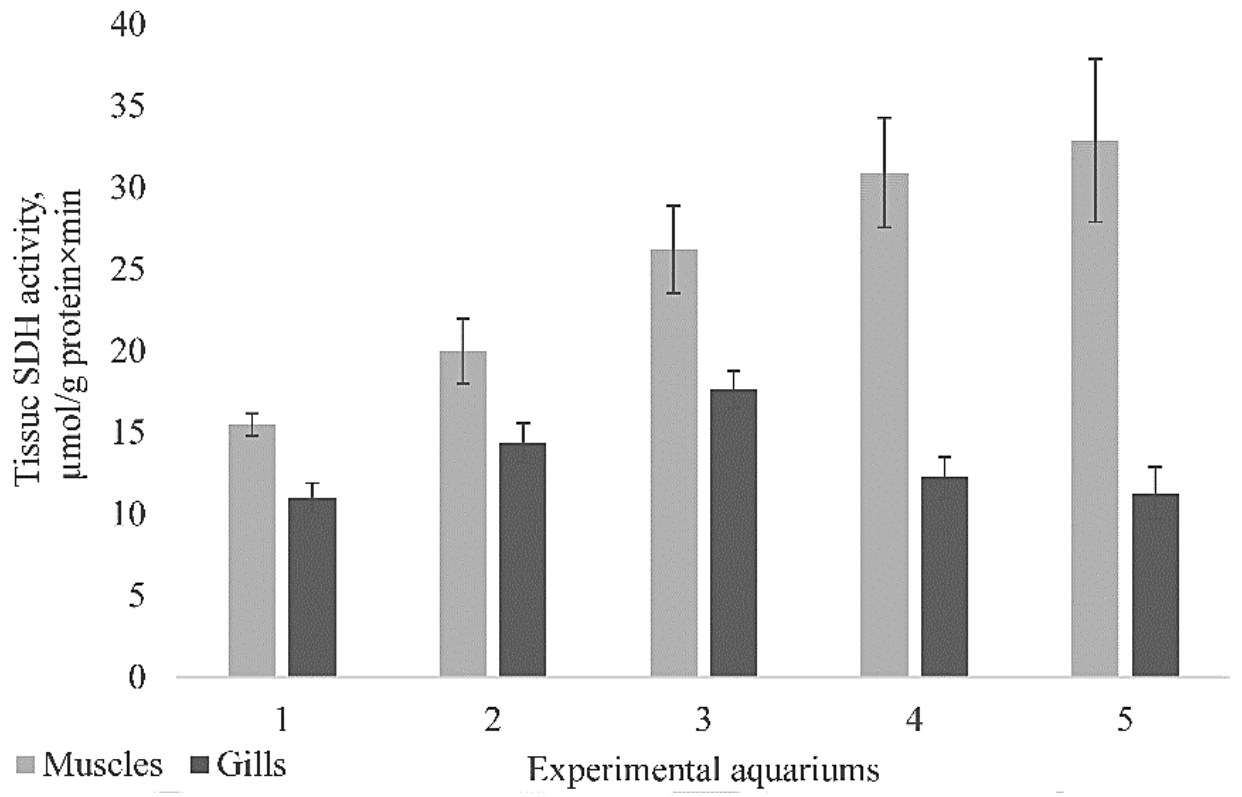

Fig. 9. The SDH activity in the tissues of young common carp under the chronic action of high concentrations of potassium monophosphate. $\mathrm{n}=40$

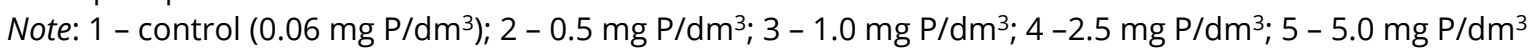

Changes in the activity of alkaline phosphatase in carp were irregular. There were no significant changes in muscle, but there was a tendency to inhibit enzyme activity relative to control (Fig. 10). In the gills of young carp, we noted significant changes in

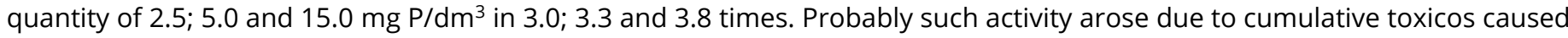
by low chronic exposure to the gills.

In muscles and gills, an increase in the GDH activity was recorded with an increase in the concentration of orthophosphates (Fig. 11). In muscle tissue, its growth was 2.8; 8.3; 5.3 and 5.3 times relative to control. In the gills, enzyme activation was 3.0; 6.1-6.3 times for control groups of fish. Such changes are probably caused by the high degree of ammonia involvement in the tricarboxylic acid cycle due to the reamination to the energy supply of the adaptive response to chronic toxic stress of the experimental environment. 


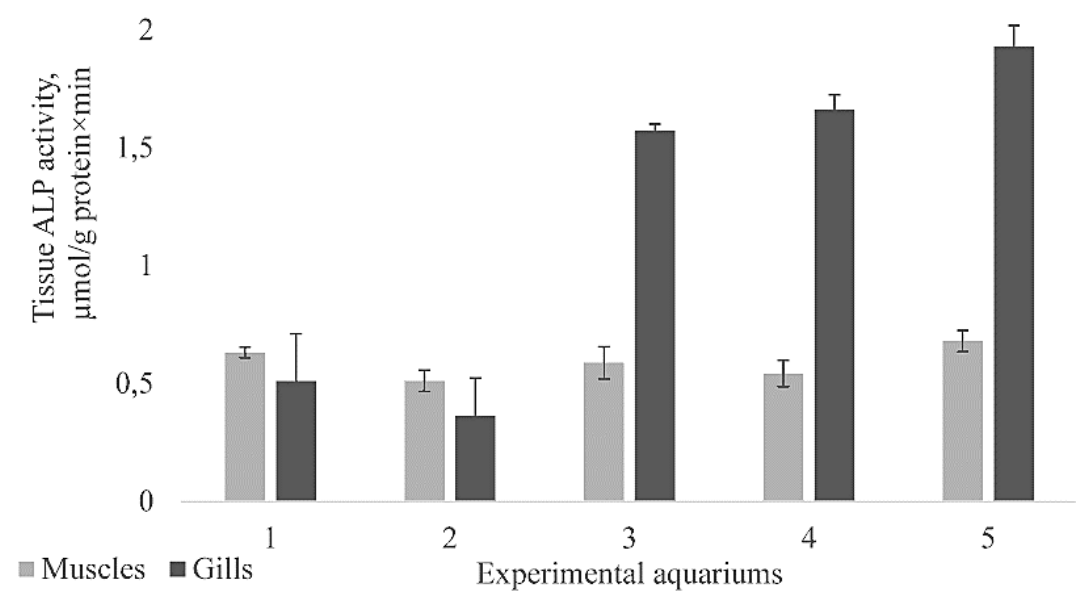

Fig. 10. The LPh activity in the tissues of young common carp under the chronic action of high concentrations of potassium monophosphate.

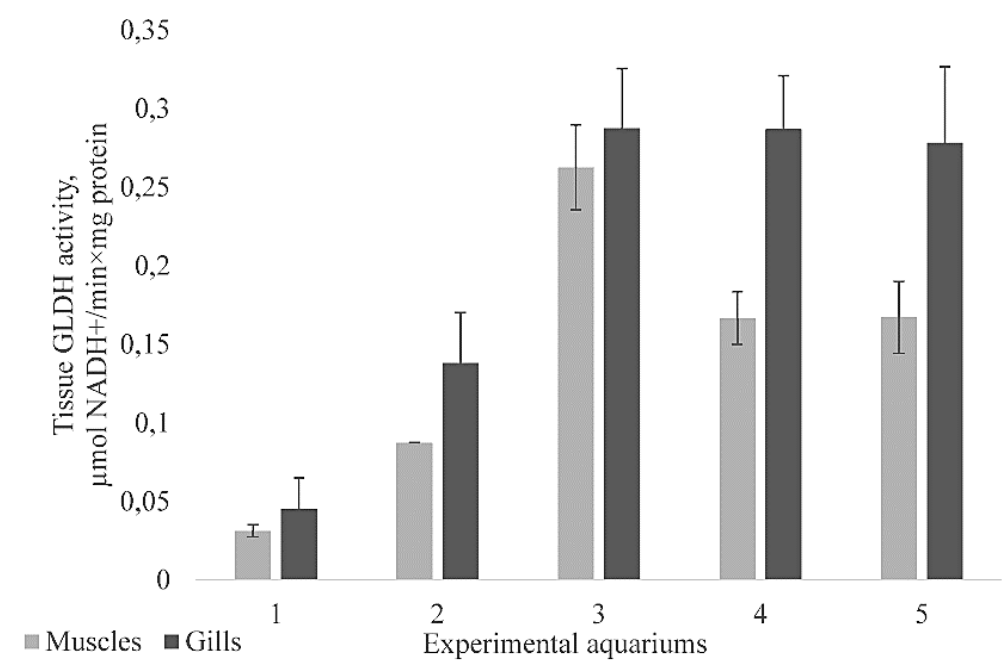

Fig. 11. The GDH activity in the tissues of young common carp under the chronic action of high concentrations of potassium monophosphate.

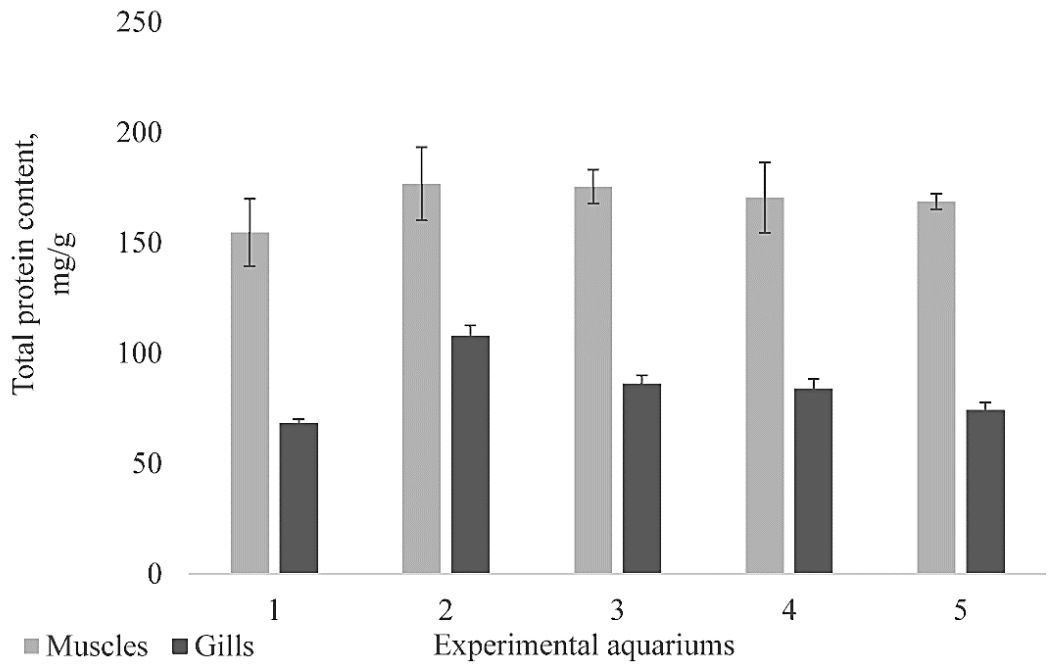

Fig. 12. The content of total protein in the tissues of young common carp under the chronic action of high concentrations of potassium monophosphate. 
The content of proteins, lipids and glycogen in carp tissues had the following changes. In muscles, there was an insignificant

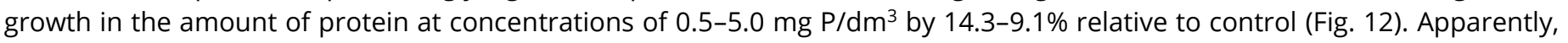
with growing up phosphorus content, carp increasingly used protein as an alternative energy source. An increase in protein at concentrations of 0.5 was recorded in the gills; 1.0 and $2.5 \mathrm{mg} \mathrm{P/dm}{ }^{3}$ at $57.8 ; 26.3$ and $23.0 \%$. At the maximum quantity of phosphorus, the growth was only $8.8 \%$ higher than control.

The lipid content was systematically reduced relative to control in both tissues. In muscle, the difference was 3.8; $12.2 ; 27,8$ and $63 \%$ below control, and in the gills 30, 52.2, 49 and 65.1\% (Fig. 13). In both tissues, the increased use of lipids to compensate for chronic toxicosis of monophosphate is evident.

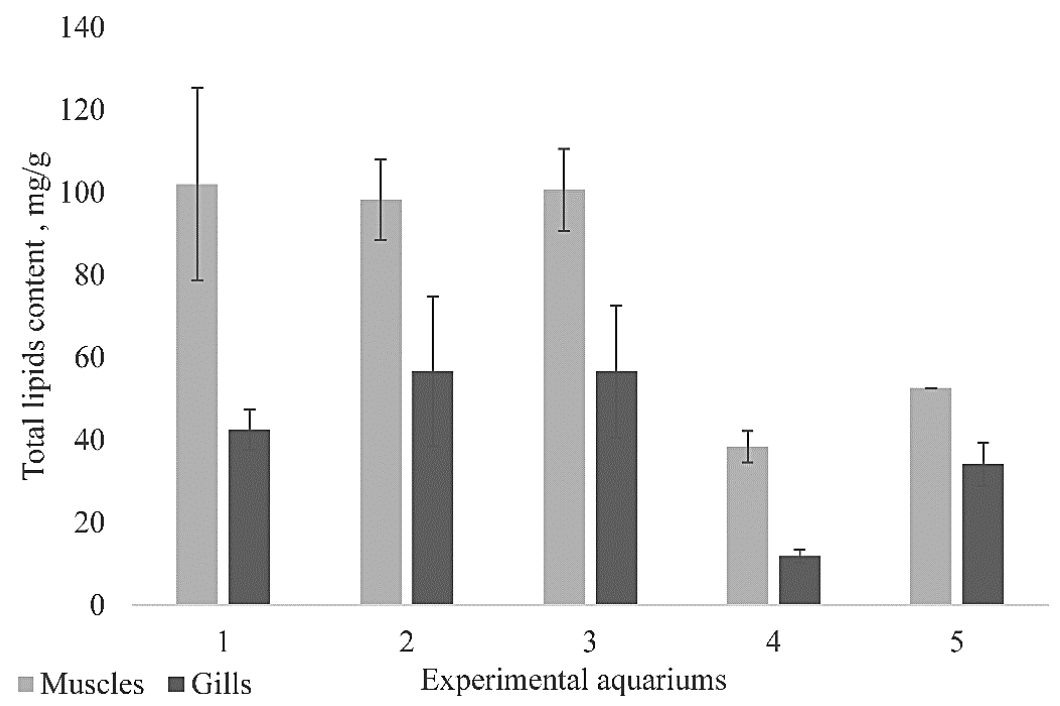

Fig. 13. The content of total lipids in the tissues of young common carp under the chronic action of high concentrations of potassium monophosphate. $n=40$

Changes in the glycogen content in both tissues did not have a clear pattern. In the muscles in amount of 0.5 and 1.0 mg P/dm ${ }^{3}$ we observed a decrease in the glycogen content by 56.6 and $77.7 \%$ (Fig. 14), and in the maximum concentration of an increase in glycogen content it was higher by $27.2 \%$ to control values. In the gills at a quantity of $0.5 \mathrm{mg}^{\mathrm{P} / \mathrm{dm}^{3}}$ there was a significant increase in glycogen content by $45 \%$, and at subsequent quantities the difference was 3.1 and $6.1 \%$ above control. At the highest concentration, the glycogen content in the gills was $34 \%$ lower than the control values. Apparently, carp activated the process of gluconeogenesis from lipids and partially from proteins to accumulate glycogen to further counteract the chronic toxicity of phosphates.

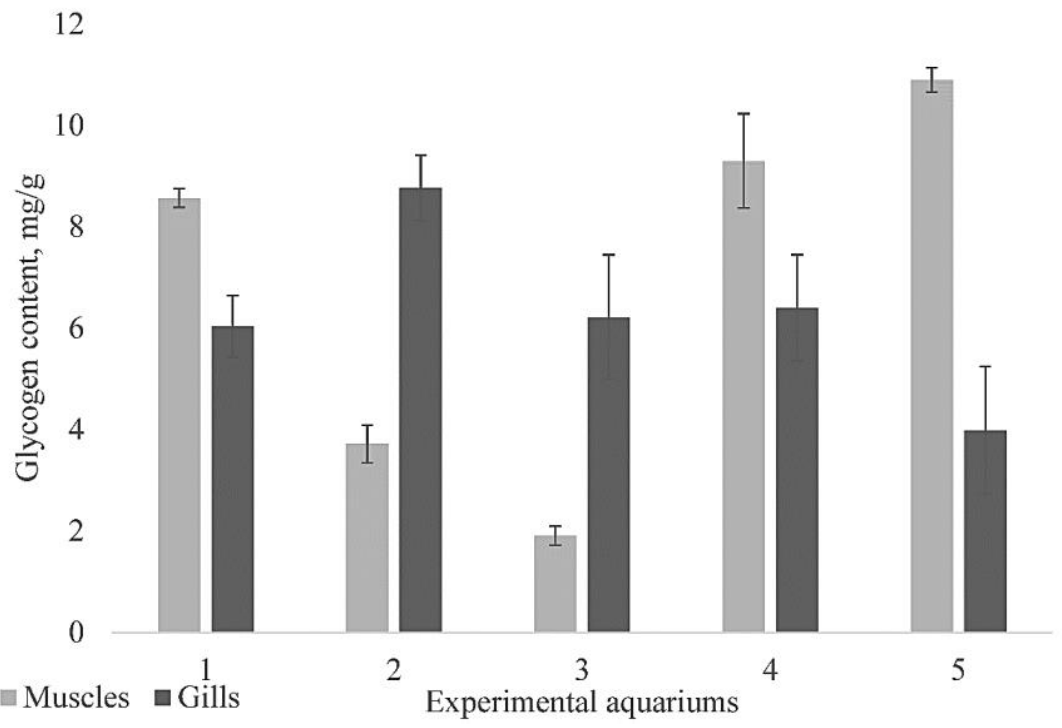

Fig. 14. The glycogen content in the tissues of young common carp under the chronic action of high concentrations of potassium monophosphate. $n=40$.

\section{Conclusions}

According to the results of the experiments, we can identify the following features in the biochemical reactions of young carp to the action of high concentrations of biogen compounds in water. 
Enzymes of energy metabolism (LDH and SDH) in muscles under the action of ammonium nitrogen reduce their activity with increasing concentration of toxin in the water. In the gills, the activity of LDH relative to control grows, which is a compensation for energy expenditure for detoxification and excretion of ammonia from the body. While the activity of aerobic energy generation pathways (SDG) is reduced. Under the action of orthophosphate ion, the activity of LDH in the muscles and gills decreases, and SDH increases in the muscles, in the gills at the highest concentrations remains unchanged.

Therefore, for different toxins, energy supply processes have different vectors: for ammonium nitrogen, the activity of anaerobic digestion of energy-intensive compounds grows directly in the organs of neutralization and excretion of nitrogen compounds, namely in the gills. In general, the body of carp under the action of ammonium nitrogen reduces the total energy consumption for maximum survival under these environmental conditions.

We revealed that under the action of phosphorus phosphates there was no change in the vector of energy supply in the direction of anaerobic metabolism, whereas the oxidation of nutrients occurred in the presence of oxygen in fish body.

The processes of immune protection and dephosphorylation, for which LPh is responsible, and the detoxification and excretion of nitrogenous substances from the body of carp (GDG) acted differently depending on the chemical nature of the toxin. Thus, under the action of ammonium nitrogen, there was an increase in the activity of enzymes in the highest concentrations of the toxin. The activity of LPh raised due to the activation of the immune response to tissue damage due to the toxin, and the activity of GDG decreased to reduce the production of ammonia, to avoid endogenous intoxication. We registered an increase in the activity of immune defense processes and the involvement of ammonia in the Krebs cycle under the action of potassium monophosphate due to reamination to energy supply to counteract the weak but chronic toxic effects of orthophosphate ion. The content of energy-intensive substances also varied depending on the chemical nature of the toxin. The influence of ammonium chloride was observed not only the use of "traditional" energy substrates - glycogen and lipids, but also the use of proteins, which indicates the high toxicity of this compound for the body of young carp. Under the action of orthophosphate ion, the active use of lipids and even the activation of gluconeogenesis at maximum concentrations, as a reaction to weak longterm chemical stress.

Thus, the acute toxicity of ammonia for the body of young carp was confirmed and the literature data on the low toxicity of orthophosphate ion for fish were confirmed. Peculiarities of the adaptive response of the carp organism to the action of toxins of biogenic origin have been revealed.

\section{References}

Adamu, K. M., \& Kori-Siakpere, O. (2011). Effects of sublethal concentrations of tobacco (Nicotiana tobaccum) leaf dust on some biochemical parameters of Hybrid catfish (Clarias gariepinus and Heterobranchus bidorsalis). Brazilian Archives of Biology and Technology, 54(1), 183-196. doi: 10.1590/S1516-89132011000100023

Bhattacharya, H., \& Lun, L. (2005). Biochemical effects to toxicity of CCl4 on rosy barbs (Puntius conchonius). Our Nature, 3(1), 20-25. doi: 10.3126/on.v3i1.330

Bojko, O. V., Darmohray, L. M., Luchyn, I. S., Honchar, O. F., \& Gutyj, B. V. (2020). Specific activity of Sr-90 and Cs-137 in rabbits of various genotypes. Ukrainian Journal of Ecology, 10 (2), 165-169. doi: 10.15421/2020_80

Boudreaux, P. J., Ferrara, A. M., \& Fontenot, Q. C. (2007). Acute toxicity of ammonia to spotted gar, Lepisosteus oculatus, alligator gar, Atractosteus spatula, and paddlefish, Polyodon spathula. Journal of the World Aquaculture Society, 38(2), 322-325.

Boyko, O. O., \& Brygadyrenko, V. V. (2019). Nematocidial activity of aqueous solutions of plants of the families Cupressaceae, Rosaceae, Asteraceae, Fabaceae, Cannabaceae and Apiaceae. Biosystems Diversity, 27(3), 227-232. doi: $10.15421 / 011931$

Camargo, J. A., \& Alonso, Á. (2006). Ecological and toxicological effects of inorganic nitrogen pollution in aquatic ecosystems: a global assessment. Environment international, 32(6), 831-849. doi: 10.1016/j.envint.2006.05.002

Ceron, J. J., Sancho, E., Ferrando, M. D., Gutierrez, C., \& Andreu, E. (1997). Changes in carbohydrate metabolism in the eel Anguilla anguilla, during short-term exposure to diazinon. Toxicological \& Environmental Chemistry, 60(1-4), 201-210. doi: 10.1080/02772249709358464

Chandravathy, V. M., \& Reddy, S. L. N. (1996). Lead nitrate exposure changes in carbohydrate metabolism of freshwater fish. Journal of Environmental Biology, 17(1), 75-79.

Chukwu, L. O., \& Okpe, H. A. (2006). Differential response of Tilapia guineensis fingerlings to inorganic fertilizer under various salinity regimes. Journal of environmental biology, 27(4), 687-690.

Cicik, B., \& Engin, K. (2005). The effects of cadmium on levels of glucose in serum and glycogen reserves in the liver and muscle tissues of Cyprinus carpio (L., 1758). Turkish Journal of Veterinary and Animal Sciences, 29(1), 113-117.

Colt, J., \& Tchobanoglous, G. (1976). Evaluation of the short-term toxicity of nitrogenous compounds to channel catfish, Ictalurus punctatus. Aquaculture, 8(3), 209-224. doi: 10.1016/0044-8486(76)90084-3

El-Shebly, A. A., \& Gad, H. A. M. (2011). Effect of chronic ammonia exposure on growth performance, serum growth hormone (GH) levels and gill histology of Nile tilapia (Oreochromis niloticus). Journal of Microbiology and Biotechnology Research, $1(4), 183-197$.

Eshchenko, N. D., \& Volskyi, H. H. (1982). Opredelenye aktvnosty suktsynatdehydrohenazy. Metody byokhymycheskykh yssledovanyi (lypydniy y enerhetycheskyi obmen). Leningrad. Leningrad University Press (in Russian).

Francis-Floyd, R., Watson, C., Petty, D., \& Pouder, D. B. (2009). Ammonia in aquatic systems. University of Florida IFAS Extension Publication. FA-16. doi: 10.1.1.520.1240 
Grynevych, N., Sliusarenko, A., Dyman, T., Sliusarenko, S., Gutyj, B., Kukhtyn, M., Hunchak, V. \& Kushnir, V. (2018). Etiology and histopathological alterations in some body organs of juvenile rainbow trout Oncorhynchus mykiss (Walbaum, 1792) at nitrite poisoning. Ukrainian Journal of Ecology, 8(1), 402-408. doi: 10.15421/2018_228

Gutyj, B. V., Ostapyuk, A. Y., Sobolev, O. I., Vishchur, V. J., Gubash, O. P., Kurtyak, B. M, Kovalskyi, Y. V., Darmohray, L. M., Hunchak, A. V., Tsisaryk, O. Y., Shcherbatyy, A. R., Farionik, T. V., Savchuk, L. B., Palyadichuk, O. R., \& Hrymak, K. (2019). Cadmium burden impact on morphological and biochemical blood indicators of poultry. Ukrainian Journal of Ecology, 9(1), 236239.

Gutyj, B., Ostapiuk, A., Kachmar, N., Stadnytska, O., Sobolev, O., Binkevych, V., Petryshak, R., Petryshak, O., Kulyaba, O., Naumyuk, A., Nedashkivsky, V., Nedashkivska, N., Magrelo, N., Golodyuk, I., Nazaruk, N., Binkevych, O. (2019). The effect of cadmium loading on protein synthesis function and functional state of laying hens' liver. Ukrainian Journal of Ecology, 9(3), 222226.

Huff, L., Delos, C., Gallagher, K., \& Beaman, J. (2013). Aquatic life ambient water quality criteria for ammonia-freshwater. Washington DC: US Environmental Protection Agency. doi: 10.2175/106143017X15131012153176

Jyothi, B., \& Narayan, G. (1997). Effect of phorate on certain protein profiles of serum in freshwater fish, Clarias batrachus (Linn.).Journal of Environmental Biology, 18(2), 137-140.

Khokhlov, A. P., Sydorova, N. V., \& Alyeva, Kh. K. (1990). Sposob opredelenija aktivnosti hlutamatdehidrohenazy v biolohicheskikh objektakh. № 1573419, Avtorskoe yzobretenye SU 1573419 Al (in Russian).

Kim, E., Yoo, S., Ro, H. Y., Han, H. J., Baek, Y. W., Eom, I. C., ... \& Choi, K. (2013). Aquatic toxicity assessment of phosphate compounds. Environmental health and toxicology, 28, e2013002 doi: 10.5620/eht.2013.28.e2013002

Kurbatova, I. M., Yevtushenko, M. Y., Zakharenko, M. O., \& Chepil, L. V. (2018). Activity of Enzymes of Blood Plasma of Carp (Cyprinus carpio) under Albendazole Impact. Hydrobiological Journal, 54(4), 72-77.

Li, M., Gong, S., Li, Q., Yuan, L., Meng, F., \& Wang, R. (2016). Ammonia toxicity induces glutamine accumulation, oxidative stress and immunosuppression in juvenile yellow catfish (Pelteobagrus fulvidraco). Comparative Biochemistry and Physiology Part C: Toxicology \& Pharmacology, 183, 1-6.

Liu, X., Tiquia, S. M., Holguin, G., Wu, L., Nold, S. C., Devol, A. H., ... \& Zhou, J. (2003). Molecular diversity of denitrifying genes in continental margin sediments within the oxygen-deficient zone off the Pacific coast of Mexico. Applied and Environmental Microbiology, 69(6), 3549-3560. doi: 10.1128/AEM.69.6.3549-3560.2003

Lotter, A. F., \& Anderson, N. J. (2012). Limnological responses to environmental changes at inter-annual to decadal time-scales. In Tracking environmental change using lake sediments (pp. 557-578). Springer, Dordrecht. doi: 10.1007/978-94-0072745-8_18

Lowry, O. H., Rosebrough, N. J., Farr, A. L., \& Randall, R. J. (1951). Protein measurement with the Folin phenol reagent. Journal of biological chemistry, 193, 265-275.

Martseniuk, V. M., Potrokhov, O. S., \& Zinkovskiy, O. G. (2017). Physiological-Biochemical Peculiarities of Adaptation of Perch and Common Carp to Elevated Water Temperature. Hydrobiological Journal, 53(6), 60-67. doi: 10.1615/HydrobJ.v53.i6.60

Martseniuk, V. M., Potrokhov, O. S., \& Zinkovskiy, O. G. (2018). Energy Metabolism in Organs and Tissues of Perch Perca fluviatilis under Changes of Water Temperature. Hydrobiological Journal, 54(4), 85-90. doi: 10.1615/HydrobJ.v54.i4.90

McKenzie, D. J., Shingles, A., Claireaux, G., \& Domenici, P. (2009). Sublethal concentrations of ammonia impair performance of the teleost fast-start escape response. Physiological and Biochemical Zoology, 82(4), 353-362. doi: 10.1086/590218

Mohamed, F. A. S., \& Gad, N. S. (2008). Environmental pollution-induced biochemical changes in tissues of Tilapia zillii, Solea vulgaris and Mugil capito from Lake Qarun, Egypt. Global Vet, 2(6), 327-336.

Naidu, N. G., Kumar, V., \& Shameem, U. (2017). Acute and sub acute toxic effect of ammonia on behavioural and haematological responses of Indian major carp Labeo rohita Ham, 1822. Int. J. Fish. Aquat. Stud., 5(2), 332-335.

Neff, J. M. (1985). Use of biochemical measurements to detect pollutant-mediated damage to fish. In Aquatic toxicology and hazard assessment: seventh symposium. ASTM International, 155-183. doi: 10.1520/STP36266S

Palanisamy, P., Sasikala, G., Mallikaraj, D., Bhuvaneshwari, N., \& Natarajan, G. M. (2012). Activity levels of phosphatases of the air-breathing catfish Mystus cavasius exposed to electroplating industrial effluent chromium. Biology and Medicine, 4(2), 60-64.

Piven, O. T., Khimych, M. S., Salata, V. Z., Gutyj, B. V., Naidich, O. V., Skrypka, H. A., Koreneva, Z. B., Dvylyuk, I. V., Gorobey, O. M., \& Rud, V. O. (2020). Contamination of heavy metals and radionuclides in the honey with different production origin. Ukrainian Journal of Ecology, 10(2), 405-409.

Potrokhov, O., Zinkovskyi, O., Prychepa, M., \& Khudiiash, Y. (2019). Hormonal Regulation of Fish Adaptation to Atypical Fluctuations in Temperature and Oxygen Regime of a Water Body. Aquatic Science and Technology, 7(2), 1-16.

Prychepa, M. V., Potrokhov, O. S., \& Zin'kovskiy, O. G. (2019). Peculiarities of Biochemical Response of Fish to Anthropogenic Load under Conditions of Urbanization. Hydrobiological journal, 55(3), 44-52. doi: 10.1615/HydrobJ.v55.i3.50

Prychepa, M. V., Potrokhov, O. S., Zin'kovskiy, O. G., \& Khudiyash, Y. M. (2019). Peculiarities of Hormonal Responses of Fishes under Temperature Water Thermal Fluctuations. Hydrobiological Journal, 55(5), 72-80. doi: 10.1615/HydrobJ.v55.i5.70

Prysiazhniuk, N., Grynevych, N., Slobodeniuk, O., Kuzmenko, O., Tarasenko, L., Bevz, O., Khomiak, O., Horchanok, A., Gutyj, B., Kulyaba, O., Sachuk, R., Boiko, O., \& Magrelo, N. (2019). Monitoring of morphological parameters of Cyprinidae liver. Ukrainian Journal of Ecology, 2019, 9(3), 162-167

Randall, D. J., \& Tsui, T. K. N. (2002). Ammonia toxicity in fish. Marine pollution bulletin, 45(1-12), 17-23. doi: 10.1016/S0025326X(02)00227-8

Randall, D. J., \& Wright, P. A. (1987). Ammonia distribution and excretion in fish. Fish physiology and biochemistry, 3(3), 107120. doi: $10.1007 / B F 02180412$ 
Rudenko, O. P., Paranjak, R. P., Kovalchuk, N. A., Kit, L. P., Hradovych, N. I., Gutyj, B. V., Kalyn, B. M., Sukhorska, O. P., Butsiak, A. A., Kropyvka, S. I., Petruniv, V. V., \& Kovalska, L. M. (2019). Influence of seasonal factors on carp fish immune reactivity. Ukrainian Journal of Ecology, 2019, 9(3), 168-173. doi: 10.15421/2019_726

Shapyro, D. K. (1976). Praktikum po biolohicheskoy khimii. Mynsk: Vyshaja shkola, 169-170 (in Russian).

Smart, G. (1976). The effect of ammonia exposure on gill structure of the rainbow trout (Salmo gairdneri). Journal of Fish Biology, 8(6), 471-475. doi: 10.1111/j.1095-8649.1976.tb03990.x

Strauch, S. M., Bahr, J., Baßmann, B., Bischoff, A. A., Oster, M., Wasenitz, B., \& Palm, H. W. (2019). Effects of Ortho-Phosphate on Growth Performance, Welfare and Product Quality of Juvenile African Catfish (Clarias gariepinus). Fishes, 4(1), 3. doi: 10.3390/fishes4010003

Sychov, M. Yu., Holubiev, M. I., Kovalchuk, V. V., Pozniakovskyi, Yu. V., Holubieva, T. A., \& Makhno, K. I. (2017). Valine needs in growing quails. Ukrainian Journal of Ecology, 7(3), 180-185.

Tilak, K. S., Lakshmi, S. J., \& Susan, T. A. (2002). The toxicity of ammonia, nitrite and nitrate to the fish, Catla catla (Hamilton). Journal of environmental biology, 23(2), 147-149.

Ulén, B. M., \& Weyhenmeyer, G. A. (2007). Adapting regional eutrophication targets for surface waters-influence of the EU Water Framework Directive, national policy and climate change. Environmental Science \& Policy, 10(7-8), 734-742. doi: 10.1016/j.envsci.2007.04.004

van Bussel, C. G., Mahlmann, L., Kroeckel, S., Schroeder, J. P., \& Schulz, C. (2013). The effect of high ortho-phosphate water levels on growth, feed intake, nutrient utilization and health status of juvenile turbot (Psetta maxima) reared in intensive recirculating aquaculture systems (RAS). Aquacultural engineering, 57, 63-70. doi: 10.1016/j.aquaeng.2013.08.003

Vodianitskyi, O., Potrokhov, O., Hrynevych, N., Khomiak, O., Khudiyash, Y., Prysiazhniuk, N., Rud, O., Sliusarenko, A., Zagoruy, L., Gutyj, B., Dushka, V., Maxym, V., Dadak, O., \& Liublin, V. (2020). Effect of reserviour temperature and oxygen conditions on the activity of Na-K pump in embrios and larvae of perch, roach, and ruffe. Ukrainian Journal of Ecology, 10(2), 184189. doi: 10.15421/2020_83

Whitehead, P. G., Wilby, R. L., Battarbee, R. W., Kernan, M., \& Wade, A. J. (2009). A review of the potential impacts of climate change on surface water quality. Hydrological sciences journal, 54(1), 101-123. doi: 10.1623/hysj.54.1.101

Wurtsbaugh, W. A., Paerl, H. W., \& Dodds, W. K. (2019). Nutrients, eutrophication and harmful algal blooms along the freshwater to marine continuum. Wiley Interdisciplinary Reviews: Water, 6(5), e1373. doi: 10.1002/wat2.1373

Zutshi, B., Noor, N., \& Sreekala, G. (2015). Assessment of protein, glycogen and activity of phosphatases of Labeo rohita in response to physico-chemical parameters of lakes of Bangalore.Assessment, 10(4), 1531-1537.

\section{Citation:}

Kofonov, K., Potrokhov, O., Hrynevych, N., Zinkovskyi, O., Khomiak, O., Dunaievska, O., Rud, O., Kutsocon, L., Chemerys, V., Gutyj, B., Fijalovych, L., Vavrysevych, J., Todoriuk, V., Leskiv, K., Husar, P., Khumynets, P. (2020). Changes in the biochemical status of common carp juveniles (Cyprinus carpio L.) exposed to ammonium chloride and potassium phosphate. Ukrainian Journal of Ecology, 10(4), 137-147. 